\title{
The Strategy of Developing the Competence of Human Resources of the State Civil Apparatus of Barru Regency Government
}

\author{
Nur Ilmiah Rivai \\ Public Administration, Universitas Pepabri Makassar \\ Email: maynamemay@gmail.com
}

(Received: January-2021; Reviewed: February-2021; Accepted: March-2021;

Avalaible Online: March-2021; Published: March-2021)

\begin{abstract}
This study aims to develop a Human Resources competency strategy at the Barru Regent's Office. This research specifically focuses on the development of Human Resources competencies used by the Barru district government in developing Human Resources apparatuses in order to perform high. This study uses a phenomenological approach, the main data collection techniques are interviews, observation Data analysis techniques used are data analysis techniques descriptive qualitative. The analysis was conducted after data collection through interviews and direct observation in the field. The results of the study include a strategy for developing resource management where competency-based apparatus people are realized by referring to the vision, mission, and goals through the remuneration mechanism as a form of appreciation for apparatus that has good performance. Development system and apparatus fulfillment system to improve apparatus competence, maintain productive human resources, improve welfare and create more positive competition. The whole process is carried out by referring to the principles of (a) human control control (b) recruit activity train, educate, develop, (d) manage Human relations performance, (e) reward and discipline action (f) manage redeployment, and (g) negotiation for working conditions.
\end{abstract}

Keywords: Development; Competence; Strategy; Apparatus.

\section{INTRODUCTION}

Good governance is a form of the government's desire to build a harmonious relationship with the community (Limpo et al., 2015; Luo, 2001; Niswaty et al., 2016; Papalapu et al., 2016; Rengifurwarin et al., 2018). This is driven by the reality that so far, there is still a tendency for the relationship to be damaged due to bureaucratic behavior that is far from upholding the principles of the rule of law. The principles of good governance are becoming more concrete by mentioning six groups of principles (feasibility, transparency, participation, effectiveness, accountability, and human rights) found in many national, regional, and international context documents (Addink, 2019). Professionalism, accountability, transparency, and participation, 
both in policy management and in providing services to the community (Cruess \& Cruess, 2008). Regional Government is the head of the region as an element of the Regional Government who leads the implementation of government affairs which fall under the authority of the autonomous region. In the implementation of governmental affairs, it must implement the principles of good governance (good governance). This is important in legal protection for products that have distinctive characteristics due to the geographical area of an area, only in that area and not owned in other areas (Giovannucci et al., 2010).

Efforts to foster and develop apparatus resources are carried out through education and training programs as stated in Law Number 43 of 1999, Article 31 which states that "in order to achieve maximum utility and utility, there will be arrangements and implementation of education and training for Civil Servant positions. (PNS) which aims to improve service, quality, expertise, abilities and skills. The strategy for education and training policies for local government officials is basically aimed at increasing knowledge, skills / expertise and proficiency in carrying out various tasks and jobs assigned to the apparatus and changing the mental attitudes of local government officials struggling in providing good public services to the community (Odden et al., 2002). The policy strategy for developing local government apparatus resources through education and training, when not accompanied by comprehensive planning, will not support the right level of competence in order to ensure organizational effectiveness and efficiency, also result in the implementation of career planning policies and career development of local government officials. some criteria for the ideal model of bureaucracy are ignored. Such as the placement arrangement is based on the ability of the apparatus, the fulfillment of the career track record requirements of the apparatus, and official, non-personal organizational relationships.

Government Regulation (PP) Number 101 of 2000 concerning Education and Training for Civil Servant Positions (PNS), in article 2 which states that education and training aims at: increasing knowledge, expertise, skills and attitudes to be able to carry out job duties professionally based on the personality and ethics of civil servants according to with the needs of agencies, creating apparatus capable of acting as reformers and the glue of national unity and integrity, strengthening attitudes and spirit of service-oriented service, protection and community empowerment, and creating a common vision and dynamic mindset in carrying out general government and development tasks for their realization. good governance.

As stated by (Williamson et al., 2010), good governance is a very broad concept that includes various processes in land management and administration. Good governance is one of the management models in the public sector. So that the quality of human resources apparatus is needed in knowledge, expertise, skills and attitudes as a strong basis for being able to carry out job duties professionally based on the personality and ethics of the bureaucrats (Khalik et al., 2020). The importance of human resource qualifications is because public organizations as organizations that provide services to the public sector need to make the human element the main problem that must be resolved immediately through its development and guidance program. According to (Amayah, 2013), that human resource management in the public sector organization is very important in terms of both the cultural context, the organizational climate and the typical managerial values of the bureaucracy that have differences with private sector organizations.

Competency-based human resource management is useful in HRM activities, including: 1) increasing organizational effectiveness by appointing individuals to positions that are in accordance with their competencies; 2) clarify the employee's career development and pattern, because with the position competency standards, individuals who wish to develop their careers can find out what they need to achieve in order to achieve that position; 3) increase the efficiency and effectiveness of competency development programs in accordance with 
organizational needs and employee career development; 4) can provide fair and proportional rewards in accordance with their respective performance; 5) provide a healthy and competitive work atmosphere through fair competency and performance assessments.

ASN or civil servants as human resources in the government sector play an important role in the success of the implementation of government administration and national development so that the position and role of civil servants is very important as executors of government business activities. Human resources in government organizations remain a key element in achieving success in achieving organizational goals. The process of human resource management within the scope of government organizations is carried out in the form of recruitment, maintenance and development. Human Resource Management (HRM) for the public sector, as an organization that has a main orientation in terms of providing quality public services to the community which makes the human component the dominant factor. HRM in this context according to (Bovaird, 2007) is the big responsibility of the bureaucracy in providing services to the community which must be supported by professional and competent Human Resources (HR). This view places the human element as one of the main elements to ensure the success of public organizations in providing public services, both goods and services with good quality. Especially if it is related to the emergence of issues about the low quality of government services (bureaucracy) to the community. This is what makes the human element the main focus that directly interacts with society. In the context of bureaucratic reform, one of the things that must be reformed in the field of public service is the quality of human beings that must be nurtured and developed in order to become a professional, responsible government apparatus.

The reality in the field shows that people still often complain about things related to the quality of public services provided by bureaucrats or officials. This issue is of course very close to the subject matter of human resources apparatus who provide direct services to the community. There needs to be significant efforts to improve the quality and professionalism of the apparatus, in addition to improving the quality of service as well as creating a better quality of apparatus professionalism (Lipsky, 2010).

The problems faced at this time are still lack of mastery and understanding and very basic tasks and functions, then the existence of creativity and innovation in work does not support the skills of the apparatus in digestion so that the quality of planning, monitoring and evaluation does not go well because it is always changing. policies and laws and regulations, resulting in less than optimal coordination within the scope of internal and external state civil servants. To respond to the development of efforts to strengthen government institutions that have apparatus that must be professional and to carry out institutional arrangements to respond to the demands of the changing times, the Barru District Civil Service Agency must have readiness to face the present and future era (Jenkins, 2009).

This reality will be one of the obstacles for the regional government in Barru Regency to be able to carry out competency-based human resource development. In order to be able to approach the ideal concept of a good government, and to be able to provide good service, to produce professional and reliable human resources, it must be supported by an increase in the competence of the apparatus. Another fact in Barru Regency is that there is a tendency for the low level of performance of the apparatus, especially the inaccuracy in assigning and transferring officials according to their competence and expertise because political intervention is dominant in recruitment, especially in the placement of employees (Hitt et al., 2006).

The weaknesses faced by the Barru Regency government are the main reason for the importance of competency-based HR competency development so that organizations can provide quality state civil servants and support the achievement of organizational goals and objectives with high performance standards. In addition, the competencies possessed by each 
employee individually can support the implementation of the organization's vision and mission through the strategic performance of government organizations (Rasyid, 2020).

The purpose of this study was to complement similar research by focusing on the study of HR competency development strategies at the Barru Regent's Office. The strength of this research is because it is focused on the formulation of a competency-based HR development strategy prototype that is adjusted to the latest policy on competency-based ASN development.

\section{METHOD}

This study uses a phenomenological approach, the main data collection techniques are (1) in-depth interviews, (2) observation to see or observe changes in social phenomena which can then be assessed for these changes. The data sources of this research were collected from primary data sources and secondary data. Primary data sources were obtained through observation and interviews with key informants (main informants) and regular informants. Meanwhile, secondary data sources were obtained through the study and analysis of various policy documents, policy processes and implementation of human resource management policies at the research locus. The technique of collecting data by means of this observation is carried out by directly observing the management activities of Human Resources development in Barru Regency, and (3) the technique of collecting data through documentation is data collection using instruments in the form of documents, notes, photographs, as well as reports that support research. The main instrument of qualitative research is the researcher himself as the main tool for collecting data so that it is easier to make adjustments to the realities in the field. The data analysis technique used is descriptive qualitative data analysis technique. The analysis was carried out after the data was collected through interviews and direct observations in the field (Umanailo, 2019).

\section{RESULT AND DISCUSSION}

This study examines and analyzes the development of competency-based human resource management at the Barru Regent's Office. This is intended to find out the strategies implemented by the Barru district government in managing and developing human resources so that they can have high performance (Penuel et al., 2007), which in the context of this research focuses on the Barru District Civil Service Agency as an institution that is responsible for the management of regional civil service in Barru Regency. Human resource competency development for the public sector is a must. Various efforts have been made by the government in order to provide excellent service to the community which as a whole relies on professional human resources. To achieve this, the Barru Regency government must be supported by human resources who have qualified capabilities. The basic philosophy has actually given birth to government policies regarding ASN (Franco et al., 2002).

This research explores scientifically the main components, namely the development of the competence of the human resources of the state civil servants and the determinants that affect the competency development of the human resources of the state civil servants in Barru district. What is meant in this research is the whole process of management of the human resource management of Barru district officials who are under the authority of the BKDD of Barru Regency in carrying out several activities, namely recruitment and selection, placement and succession, Pays Skill / Competencies and performance Management, and Career Pathing and Development. The research generally found that through (a) the preparation of a rational classification of civil servant positions, as material for the preparation of a job map for each organizational unit of the Barru district government, (b) the preparation of competency standards for civil servant positions as benchmarks for civil servant performance, and (c) the 
preparation of a performance appraisal system. Employees who are oriented towards competency standards and organizational mission are a general model for the development of human resources for apparatus in Barru Regency. This research then reconstructs a prototype model for the development of HR Apparatus competencies in the Barru Regency government in improving managerial competence, professional competence carried out by the Barru district government (Habibi et al., 2019).

The initial stages of this research, first research and determine whether Barru district in the management of human resources has been oriented to competency-based ASN policies (Pavlova, 2008). This must be supported by several policies and planning documents that demonstrate the implementation of competency-based HRM development. This search is still being carried out at the BKDD of Barru Regency as a representation of the development of ASN in Barru Regency. In addition, it is also tracing the recruitment (procurement), maintenance (maintenance) and development (development) of HRM in Barru Regency.

The preliminary findings of the research which are used as the basis for building research assumptions that in Barru Regency, several legal foundations that serve as the legal basis are Government Regulation Number 38 of 2007 concerning the Division of Government Affairs between the Government, Provincial Government, and Regency / City Government (State Gazette of the Republic of Indonesia 2007 Number 82, Supplement to the State Gazette of the Republic of Indonesia Number 4737); Government Regulation Number 41 of 2007 concerning Regional Apparatus Organization (State Gazette of the Republic of Indonesia of 2007 Number 89, Supplement to the State Gazette of the Republic of Indonesia Number 4741); Regulation of the Minister of Home Affairs Number 57 of 2007 concerning Technical Guidelines for Organizational Structuring of Regional Apparatus; Presidential Decree of the Republic of Indonesia Number 159 of 2000 concerning Guidelines for the Establishment of Regional Civil Service Bodies; and Regulation of the Minister of Home Affairs Number 57 of 2007 concerning Technical Guidelines for Organizational Structuring of Regional Apparatus. The basis for this policy emphasizes that the Barru Regency Government in managing ASN has an orientation to Competency-based ASN management (De Baere, 2008).

Another legal basis on which to build assumptions is the readiness of the Barru district government in preparing preconditions for implementing Law no. 5 of 2014 concerning the State Civil Apparatus (ASN). The enforcement of the ASN Law means that the development of HRM must be carried out by referring to the requirement for ASN to have competence in three categories, namely; technical competence, managerial competence and socio-cultural competence. Because this research refers to the competence of ASN in Barru Regency, the aspects of the study that are the focus of the research are the efforts made by the government in improving the technical, managerial and socio-cultural competences of employees within the scope of the Barru district government which is under the BKDD leading sector ( Regional Civil Service and Training Center) City District. Thus this study does not attempt to measure the level of competence of employees in Barru Regency but is more focused on aspects of the ASN development strategy in order to meet the competencies needed by the Barru district government organization. In detail, the results of the research will be described coherently based on the research focus that has been prepared previously, namely the strategy for developing the competency of ASN human resources in Barru Regency (Gasim et al., 2019).

The focus of this research on the strategy of developing the competence of the State Civil Servant Human Resources in the Barru Regency government is traced through data collection in the form of interviews and documentation studies to then formulate a synthesis as a data display data collection process and conclution in the form of a synthesis of the results of the raw data obtained by the researcher. The development of the competence of the Human Resources of the State Civil Apparatus in the Barru Regency government is the whole process of managing the 
human resource management of the Barru district apparatus. The development strategy in this research is identified through indicators (1) control human resources (HR), namely ensuring that HR is planned, implemented and monitored appropriately and correctly in relation to the goals and objectives desired by the organization; (2) recruit activity, namely attention to the position of human resources in line with the needs of the organization, both from internal and external sources to obtain the right human resources; (3) train, educate, develop, namely activities directed at upgrading the capabilities of all existing human resources according to the needs of the organization; (4) manage HR performance, namely activities directed at determining various individual targets, monitoring progress and development based on predetermined targets and identifying training, development and education needs in response to performance appraisal results before determining good action in the form of reward and discipline action; (5) manage redeployment, namely activities to identify deficiencies in job positions that cannot be rectified either through training, development or education aimed at redeployment for job / position holders both inside and outside the organization; and (6) negotiation for working conditions, namely activities aimed at meeting human resource needs and achieving organizational goals (Cruzes et al., 2015).

Based on the results of interviews and planning document data from the BKDD of Barru Regency, it is known that the implementation of Human Resources control in Barru Regency is carried out in competency-based HR development based on Law Number 5 of 2014 concerning State Civil Apparatus (ASN Law). This enforcement includes planning, recruitment, career development, rewards, and retirement / retirement. HR planning to meet the needs of employees who meet the competency prerequisites is prepared starting from Requirements Planning, Number Arrangement, Position, Procurement and distribution of ASN; Audit or Assessment, Career Development Planning, Career Patterns, Promotions and ASN Movements; is intended to build Integrity and Discipline. Although not entirely based on competence and performance because it still refers to Law Number 43 of 1999 concerning amendments to Law Number 8 of 1974 concerning Personnel Principles (Civil Service Law). The research findings show that the implementation of ASN policies on the aspect of HR management ensures that human resources (HR) is controlled, namely ensuring that HR is carried out in a planned, executed and monitored manner in an appropriate and correct manner in achieving organizational goals and objectives. In the planning aspect, a control and monitoring mechanism is implemented on HR planning in Barru Regency in the activities of (1) recruitment and placement of employees, (2) placement of ASN in Supervisory, Administrator, and High Leadership positions, (3) monitoring employee career patterns to place ASN at the position according to the competence it has. The appraisal mechanism is carried out for career development promotion and employee transfer based on Government Regulation Number 41 of 2007 or Law Number 23 of 2014 concerning Regional Government although it has not been integrated with the development of career patterns (Pynes, 2008).

The recruitment activity is included in the HRM planning document, although it is not specific to the potential-based employee development planning. The HRM Planning Document contains (1) employee recruitment based on calculation of need (2) certification based on Government Regulation Number 18 of 2016 concerning Regional Apparatus that, each leader of the regional apparatus must have government competence as evidenced by a certification held by the Domestic Government Organizer Certification Agency (LSP-PDN) and (3) employee competency development through training. In implementing employee recruitment in Barru Regency, it is measured through a competency test to measure technical competence, personality competence, and managerial competence to fill certain predetermined formations. Even so, there are still several functional positions that still have to be supported by adequate 
professional potential so that the policies for Requirements Planning, Number Arrangement, Position, Procurement and distribution of ASN must still be well organized.

Apart from being implemented for leadership training and technical and functional training, it is carried out based on competence, especially for functional training carried out by each SKPD. Types and functional levels for each position are determined by the Functional Position Development Agency from the SKPD. Fulfillment of positions with competencies fulfilled in accordance with the qualifications of innovative abilities to foster excellent service orientation. Another strategy that is carried out in order to upgrade the capabilities of the human resources of the apparatus is to modify and create new and innovative ways of working in order to create high performance in each SKPD.

The implementation of manage HR performance, in Barru Regency, is an activity directed at determining various individual targets, monitoring progress and development based on predetermined targets as well as identifying training, development and education needs in response to the results of performance appraisals before determining good actions in the form of reward and discipline action; determined by a separate mechanism which becomes the BKD's internal policy.

Manage redeployment, as an activity to identify deficiencies in job positions that cannot be rectified either through training, development or education directed at redeployment for job / position holders both inside and outside the organization; Overcoming deficiency in positions in Barru Regency is carried out by referring to government policies, namely (1) Government Regulation Number 101 of 2000 concerning Education and Training for Civil Servants, (2) attachment to Government Regulation Number 13 of 2002 concerning amendments to Government Regulation Number 100 of 2002 concerning Appointment Civil servants in structural positions, and (3) Decree of the Head of BKN Number 64A of 2003 concerning Guidelines for the Preparation of Competency Standards for Structural Position for Civil Servants. Even so, to avoid work deficiency, the implementation of these policies must be tightened.

Fulfillment of human resource needs is carried out through training, transfer and promotion mechanisms to place employees according to their competence. This step is a form of negotiation for working conditions, namely activities aimed at meeting human resource needs and achieving organizational goals (Budi et al., 2015; Limpo et al., 2015; Minbaeva, 2008; M. S. Saggaf et al., 2018; S. Saggaf et al., 2014).

\section{CONCLUSION}

The competency-based HRM ASN development strategy in Barru Regency is realized by referring to the BKDD's vision, mission, and objectives through a remuneration mechanism as a form of appreciation for ASNs that have good performance. This process is carried out through the development of competency-based ASN which is carried out through the process of performance mapping and employee competency mapping, implementing maintenance systems, development systems and ASN compliance systems to improve ASN competencies, maintain productive human resources, improve health and create more positive competition. The whole process is carried out by referring to the principles of (a) human resource control (b) recruit activity train, educate, develop, (d) manage HR performance, (e) reward and discipline action (f) manage redeployment, and (g) negotiation. for working conditions.

\section{REFERENCES}

Addink, H. (2019). Good governance: Concept and context. Oxford University Press.

Amayah, A. T. (2013). Determinants of knowledge sharing in a public sector 
organization. Journal of Knowledge Management.

Bovaird, T. (2007). Beyond engagement and participation: User and community coproduction of public services. Public Administration Review, 67(5), 846-860.

Budi, R., Akib, H., Jasruddin, \& Dirawan, G. D. (2015). Public information management services in South Sulawesi. International Journal of Applied Business and Economic Research, 13(4).

Cruess, R. L., \& Cruess, S. R. (2008). Expectations and obligations: professionalism and medicine's social contract with society. Perspectives in Biology and Medicine, 51(4), 579-598.

Cruzes, D. S., Dybå, T., Runeson, P., \& Höst, M. (2015). Case studies synthesis: a thematic, cross-case, and narrative synthesis worked example. Empirical Software Engineering, 20(6), 1634-1665.

De Baere, G. (2008). Constitutional principles of EU external relations. Oxford University Press, USA.

Franco, L. M., Bennett, S., \& Kanfer, R. (2002). Health sector reform and public sector health worker motivation: a conceptual framework. Social Science \& Medicine, 54(8), 1255-1266.

Gasim, H., Tahir, A., Pomalato, S. W. D., \& Hatu, R. A. (2019). Implementation of Open JPTP Fulfillment Policy to Improve Leadership Competence the Area of Gorontalo Government (Case Study of Open Selection 2016).

Giovannucci, D., Barham, E., \& Pirog, R. (2010). Defining and marketing "local" foods: Geographical indications for US products. The Journal of World Intellectual Property, 13(2), 94-120.

Habibi, B., Hartinah, S., Umam, R., Syazali, M., Lestari, F., Abdurrahman, A., \& Jauhariyah, D. (2019). Factor determinants of teacher professionalism as development of student learning education at school of SMK PGRI in Tegal City, Indonesia. Journal of Gifted Education and Creativity, 6(2), 123-132.

Hitt, M. A., Bierman, L., Uhlenbruck, K., \& Shimizu, K. (2006). The importance of resources in the internationalization of professional service firms: The good, the bad, and the ugly. Academy of Management Journal, 49(6), 1137-1157.

Jenkins, H. (2009). Confronting the challenges of participatory culture: Media education for the 21st century. The MIT Press.

Khalik, M. F., Asbar, A., \& Elihami, E. (2020). The Quality Of Human Resource In Enrekang District. Jurnal Edukasi Nonformal, 1(1), 63-71.

Limpo, H. Y., Akib, H., \& Dirawan, G. D. (2015). Policy formulation for the initiative right of people's representative councilof South Sulawesi. International Journal of Applied Business and Economic Research, 13(4).

Lipsky, M. (2010). Street-level bureaucracy: Dilemmas of the individual in public service. Russell Sage Foundation. 
Luo, Y. (2001). Toward a cooperative view of MNC-host government relations: Building blocks and performance implications. Journal of International Business Studies, 32(3), 401-419.

Minbaeva, D. B. (2008). HRM practices affecting extrinsic and intrinsic motivation of knowledge receivers and their effect on intra-MNC knowledge transfer. International Business Review, 17(6), 703-713.

Niswaty, R., Darwis, M., Alimuddin, W., \& Salam, R. (2016). Pengaruh Penerapan Prinsip Good Governance terhadap Efektivitas Kerja Pegawai. Jurnal Ilmiah Administrasi Publik (JIAP), 95-100.

Odden, A., Odden, A. R., \& Kelley, C. (2002). Paying teachers for what they know and do: New and smarter compensation strategies to improve schools. Corwin Press.

Papalapu, D. M., Nawawi, J., Tahir, H., \& Akib, H. (2016). The role of the department of social in empowering the street children in Makassar. International Journal of Economic Research, 13(1).

Pavlova, M. (2008). Technology and vocational education for sustainable development: Empowering individuals for the future (Vol. 10). Springer Science \& Business Media.

Penuel, W. R., Fishman, B. J., Yamaguchi, R., \& Gallagher, L. P. (2007). What makes professional development effective? Strategies that foster curriculum implementation. American Educational Research Journal, 44(4), 921-958.

Pynes, J. E. (2008). Human resources management for public and nonprofit organizations: A strategic approach (Vol. 30). John Wiley \& Sons.

Rasyid, A. R. (2020). Prototype of the Strategy for the Development of HR Competencies in the State Civil Service in Barru Regency. Jurnal Ilmiah Ilmu Administrasi Publik, 10(1), 133-142.

Rengifurwarin, Z. A., Akib, H., Jasruddin, \& Salam, R. (2018). Snapshot of public service quality in the center for integrated business service (CIBS), cooperative micro small and medium enterprises (CMSME), Maluku province, Indonesia. Journal of Entrepreneurship Education, 21(3).

Saggaf, M. S., Akib, H., Salam, R., Baharuddin, A., \& Kasmita, M. (2018). The Quality Analysis Of Academic Services.

Saggaf, S., Salam, R., Kahar, F., \& Akib, H. (2014). Pelayanan Fungsi Administrasi Perkantoran Modern. Jurnal Ad'ministrare, 1(1), 20-27.

Umanailo, M. C. B. (2019). Overview phenomenological research.

Williamson, I., Enemark, S., Wallace, J., \& Rajabifard, A. (2010). Land administration for sustainable development. Citeseer. 
276 | Pinisi Discretion Review

Volume 4, Issue 2, March 2021 Page. 267- 276 